\title{
Electrocatalytic Oxidation of Thiosulfate at Glassy Carbon Electrode Chemically Modified with Cobalt Pentacyanonitrosylferrate
}

\author{
Reza E. Sabzi \\ Department of Chemistry, Faculty of Science, University of Urmia, Urmia, Iran
}

\begin{abstract}
Um filme eletroativo fino, de pentacianonitrosilferrato de cobalto (CoPCNF), foi eletrodepositado em um eletrodo de carbono vítreo por voltametria cíclica. O eletrodo modificado exibe boa atividade eletrocatalítica frente à oxidação de tiossulfato. A oxidação eletrocatalítica de tiossulfato em eletrodo de carbono modificado com CoPCNF, como um eletrodo de trabalho, tem sido estudada usando-se voltametria cíclica, voltametria com eletrodo de disco rotatório (RDE) e cronoamperometria, em uma solução de $0,25 \mathrm{~mol} \mathrm{~L}^{-1} \mathrm{KNO}_{3}$, como eletrólito de suporte. Um gráfico de Tafel, obtido dos voltamogramas, indicou como etapa determinante na velocidade da reação de oxidação do tiossulfato, o processo de transferência de carga de um elétron. A cinética da reação catalítica foi investigada e o valor médio da constante de velocidade $(\mathrm{k})$ para a reação catalítica e o coeficiente de difusão (D) foram avaliados por diferentes aproximações para tiossulfato. Foram encontrados os valores de $(5,61 \pm 0,14) \times 10^{2}\left(\mathrm{~mol} \mathrm{~L}^{-1}\right)^{-1} \mathrm{~s}^{-1}$ e $(6,59 \pm 0,70) \times 10^{-6} \mathrm{~cm}^{2} \mathrm{~s}^{-1}$, respectivamente.
\end{abstract}

An electroactive thin film of Cobalt pentacyanonitrosylferrate (CoPCNF) was electrodeposited on a glassy carbon electrode by cyclic voltammetry. The modified electrode exhibits good electrocatalytic activity toward oxidation of thiosulfate. The electrocatalytic oxidation of thiosulfate at glassy carbon electrode modified with $\mathrm{CoPCNF}$ as a working electrode has been studied by using cyclic voltammetry, rotating disk electrode (RDE) voltammetry and chronoamperometry in a solution of $0.25 \mathrm{~mol} \mathrm{~L}^{-1} \mathrm{KNO}_{3}$ as a supporting electrolyte. A Tafel plot, derived from voltammograms indicated a one-electron charge transfer process, at rate determining step in the catalytic oxidation of thiosulfate. The kinetics of catalytic reaction was investigated and the average value of the rate constant $(\mathrm{k})$, for the catalytic reaction and the diffusion coefficient (D) were evaluated by different approaches for thiosulfate and found to be $(5.61 \pm$ $0.14) \times 10^{2}\left(\mathrm{~mol} \mathrm{~L}^{-1}\right)^{-1} \mathrm{~s}^{-1}$ and $(6.59 \pm 0.70) \times 10^{-6} \mathrm{~cm}^{2} \mathrm{~s}^{-1}$ respectively.

Keywords: modified-electrode, glassy carbon electrode, cobalt pentacyanonitrosylferrate, electrocatalytic oxidation of thiosulfate

\section{Introduction}

Among the various mediators used for electrode modification, solid metal hexacyanoferrates have attracted the attention of electrochemists as excellent electron transfer mediators, since their redox reactions can precede without dissolution of solid compounds as the ion diffusion maintains charge balance inside the solid compound. ${ }^{1-10}$ The metal pentacyanonitrosylferrate (MPCNF), a class of polynuclear mixed valence compounds, also have attracted much attention for the preparation of thin films on electrodes in the last years. ${ }^{11-20}$ The MPCNF modified electrodes used for electrocatalytic oxidation of iodide, ${ }^{11}$ nitrite, ${ }^{12}$ sulfite, ${ }^{13,14}$ hydrazine, ${ }^{16,18}$ and ascorbic acid ${ }^{20}$ and in this studies, $\mathrm{M}$ at

* e-mail: rezasabzi@yahoo.com
MPCNF modified electrode was $\mathrm{Ni},{ }^{11,18,20} \mathrm{Pd},{ }^{12,15} \mathrm{Co},{ }^{13,16}$ They act as mediators in electron transfer from substrate to electrode materials, and the most important feature of the chemically modified electrodes (CMEs), are the electrocatalysis of slow electron transfer reactions. The MEs enhance the rate of electron transfer by reducing the over potential associated with a reaction, therefore such electrocatalysis enables a high current density (i.e. increased sensitivity) to be obtained for a poor kinetic reaction at a potential close to the equilibrium potential. The CMEs are widely used in many areas such as electroanalysis, ${ }^{21,22}$ and electrocatalytic oxidation of hydrazine,,$^{23,24}$ dopamine, ${ }^{25,26}$ morphine,,$^{27}$ ascorbic acid, ${ }^{28-32}$ hydrogen peroxide, ${ }^{33}$ L-cysteine, ${ }^{34}$ iodide. ${ }^{11}$

We recently reported on the preparation of a cobalt pentacyanonitrosylferrate film modified glassy carbon electrode $(\mathrm{CoPCNF} / \mathrm{GC}),{ }^{16}$ and in the present work I plan 
to examine the electrocatalytic properties of the CoPCNF/ GC electrode toward the electroxidation of thiosulfate using various electroanalytical procedures. A CoPCNFmodified electrode was prepared as a new ME and examined for its electrocatalytic properties. This electrode has been prepared in a short time and it has shown a good response to the electrooxidation of thiosulfate. Further, its response is fast. The prepared electrode exhibited a high stability, and no loss of electroactivity of a modified electrode was found for a continuous sweep of the potential for 300 cycles. It is also intended to determine the kinetic parameters.

\section{Experimental}

\section{Apparatus}

Electrochemical experiments were carried out at $25 \pm$ $1{ }^{\circ} \mathrm{C}$ using an AUTOLAB PGSTAT-30 potentiostat/ galvanostat. A conventional three-electrode cell was used at room temperature. A saturated calomel electrode, platinum wire, and a glassy carbon disk modified electrode of $0.0314 \mathrm{~cm}^{2}$ surface area were used as reference, auxiliary, and working electrodes, respectively. A rotating electrode system (Model 682 from Metrohm) was employed.

\section{Reagents}

$\mathrm{CoCl}_{2}, \mathrm{Na}_{2}\left[\mathrm{Fe}(\mathrm{CN})_{5} \mathrm{NO}\right]$ (nitroprusside), $\mathrm{KNO}_{3}$ and thiosulfate were of analytical grade from Merck, and used without further purification. All solutions were prepared with doubly distilled water. A solution of $0.25 \mathrm{~mol} \mathrm{~L}^{-1}$ $\mathrm{KNO}_{3}$ was used as a supporting electrolyte.

\section{Electrode preparation}

The glassy carbon electrode surface is polished with $0.05 \mu \mathrm{m}$ alumina powder on the wet polishing cloth. The polished electrode is rinsed with distilled water for several times. For prepation of the modified electrode, first the metalic cobalt is deposited from a $20 \mathrm{mmol} \mathrm{L}^{-1} \mathrm{CoCl}_{2}+0.1$ mol L-1 $\mathrm{KNO}_{3}$ (plating solution) on the glassy carbon electrode by applying a constant cathodic current of 0.1 $\mathrm{mA}$ for 10-40 s depending on the desired thickness. The glassy carbon electrode covered by metallic cobalt was immersed in $0.25 \mathrm{~mol} \mathrm{~L}^{-1} \mathrm{KNO}_{3}+50 \mathrm{mmol} \mathrm{L}^{-1} \mathrm{Na}_{2}$ $\left[\mathrm{Fe}^{\mathrm{II}}(\mathrm{CN})_{5} \mathrm{NO}\right]$ solution (derivatization solution) and derivatized by cycling the electrode potential between 0.2 and $0.75 \mathrm{~V}$ until a stable voltammogram is observed (about 30 cycles with potential scan rate of $50 \mathrm{mVs}^{-1}$ ). The total surface area of the electrode, $\Gamma^{0}$, was determined from the area under anodic cyclic voltammograms of GCCoPCNF electrode.

\section{Results and Discussion}

\section{Cyclic voltammetric studies}

Cyclic voltamogramms of CoPCNF-modified glassy carbon electrode between 0 and $1 \mathrm{~V}$ exhibit a pair of peaks with a formal potential, $\mathrm{E}^{\mathrm{o}^{\prime}}=\left(\mathrm{E}_{\mathrm{pa}}+\mathrm{E}_{\mathrm{pc}}\right) / 2$, of 520 $\mathrm{mV}$ versus SCE. We observed that this peak is not affected by stirring of electrolyte, offering proof that the material is well associated with the electrode surface under the solution conditions. Figure 1 shows the cyclic voltammograms of the GC electrode (curve a) and GC/CoPCNF electrode in the absence (curve b) and presence of 10 mmol L-1 thiosulfate (curve c) in $0.25 \mathrm{~mol} \mathrm{~L}^{-1} \mathrm{KNO}_{3}$; as seen in Figure 1 the ratio $\mathrm{I}_{\mathrm{pa}} / \mathrm{I}_{\mathrm{pc}}$ remains almost unity, as expected for a surface-type behavior. The voltammograms exhibit a pair of peaks with a peak potential separation, $\Delta \mathrm{E}=\mathrm{E}_{\mathrm{pa}}-\mathrm{E}_{\mathrm{pc}}$, of $25 \mathrm{mV}$ at a scan rate of $20 \mathrm{mVs}^{-1}$. After addition of $10 \mathrm{mmol} \mathrm{L}^{-1}$ thiosulfate, an increase in the anodic peak current is observed, whereas the cathodic peak have depressed This behavior is typical of that expected for mediated oxidation, but under the same conditions at a bare GC electrode, no peak is observed (curve a). The height of the anodic peak increases with increasing thiosulfate concentration and the plot of $I_{p}$ versus thiosulfate concentration $(\mathrm{I}=\mathrm{f}(\mathrm{C}))$ between $0.2^{\mathrm{p}}$ $16 \mathrm{mmol} \mathrm{L}^{-1}$ is linear (Figure $2 \mathrm{~B}$ ).

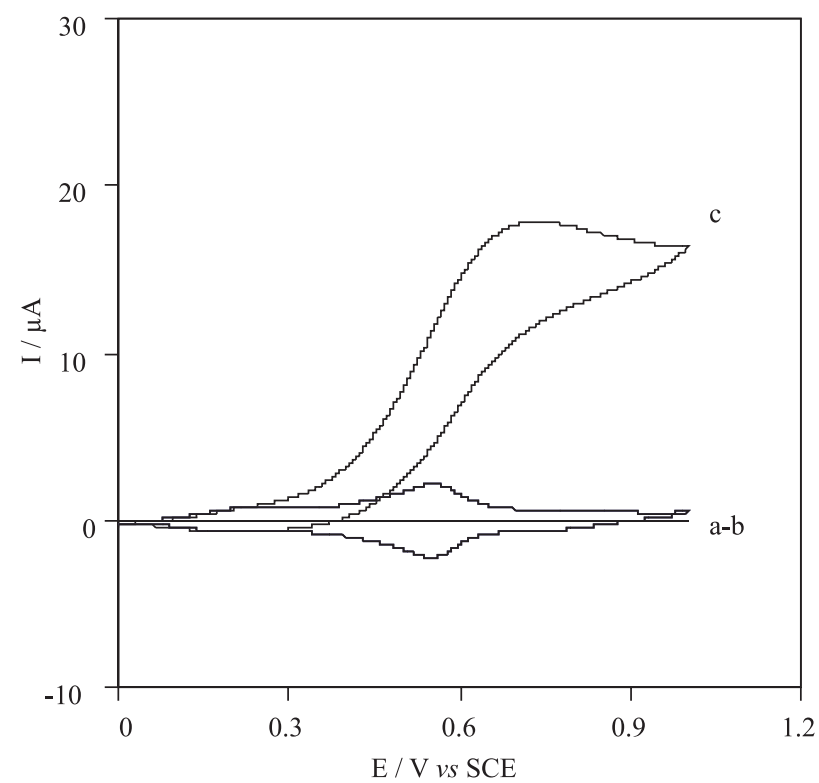

Figure 1. Cyclic voltammograms of a) GC electrode b) GC / CoPCNF in absence and c) in the presence of $10 \mathrm{mmol} \mathrm{L}^{-1}$ thiosulfate in a 0.25 mol L-1 $\mathrm{KNO}_{3}$ solution. Scan rate of $20 \mathrm{mVs}^{-1}$. 

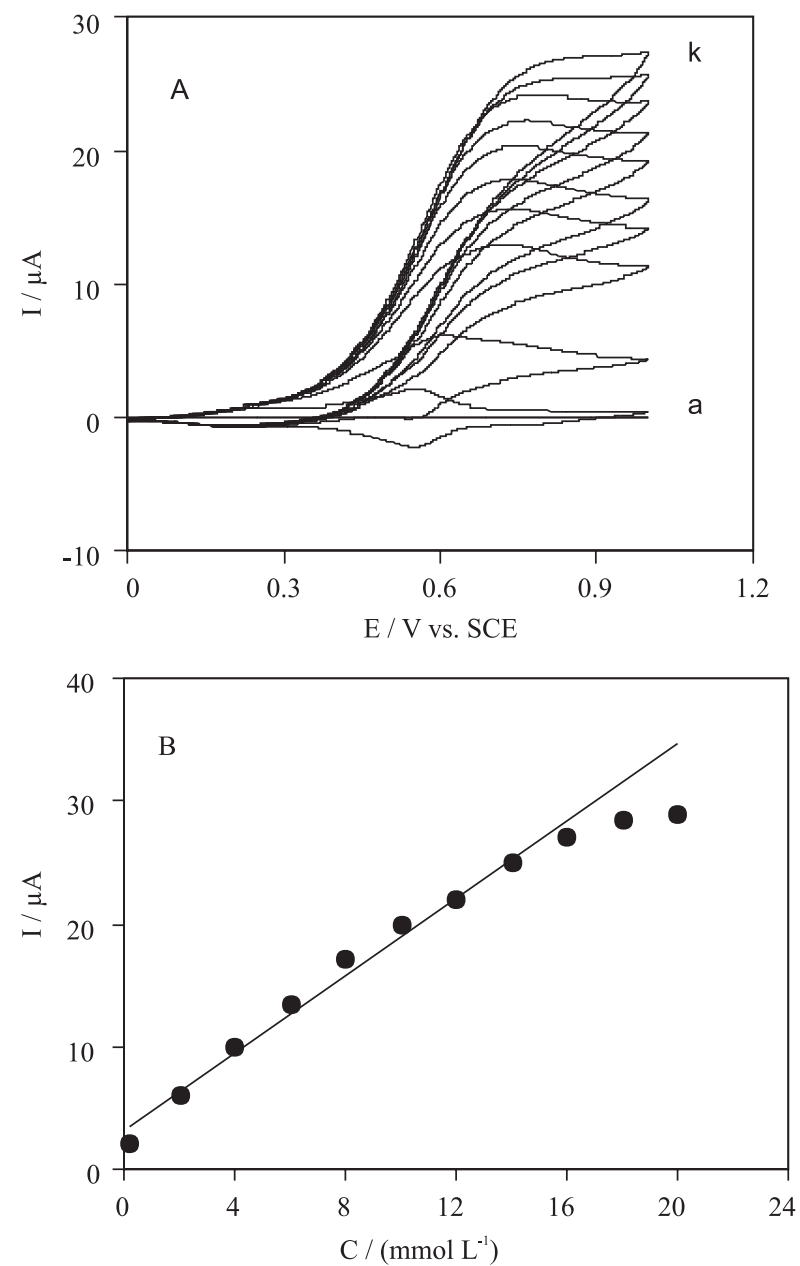

Figure 2. A) The CoPCNF / GC modified electrode with a surface coverage of $5 \times 10^{-8} \mathrm{~mol} \mathrm{~cm}^{-2}$ in the absence (a) and presence of thiosulfate over a concentration range of $2-16 \mathrm{mmol} \mathrm{L}^{-1}(\mathrm{k})$; B) the variation of the anodic peak currents $v s$ thiosulfate concentration.

In order to obtain information on the number of electrons involved in the rate-determining step, a Tafel plot was drawn using data from the rising part of the current-voltage curves $(0.3-0.5 \mathrm{~V}$, where a concentration polarization can not be occur) at a scan rate of $20 \mathrm{mV} \mathrm{s}^{-1}$. For three different concentrations of 2, 4 and $6 \mathrm{mmol} \mathrm{L}^{-1}$ of thiosulfate, the value of slope was $5.2 \mathrm{~V}$ decade $^{-1}$, independent of thiosulfate concentration, presenting a one-electron process is rate limiting, assuming a transfer coefficient of $\alpha=0.69$. Figure 3 shows a typical Tafel plot in presence of $4 \mathrm{mmol} \mathrm{L}-1$ thiosulfate.

From the plot of $\mathrm{E}_{\mathrm{pa}} v s \log v$ for the oxidation of 4 mmol L-1 thiosulfate, as is shown in Figure 4 the Tafel slope can also be obtained from the following equation: ${ }^{35}$

$\mathrm{E}_{\mathrm{pa}}=\mathrm{b} / 2 \log v+$ constant

The evaluated slope of $\mathrm{E}_{\mathrm{pa}} v s \log v$ is $95 \mathrm{mV}$, this value of the slope also indicated that a one electron transfer is rate determining step assumption transfer coefficient of $\alpha$

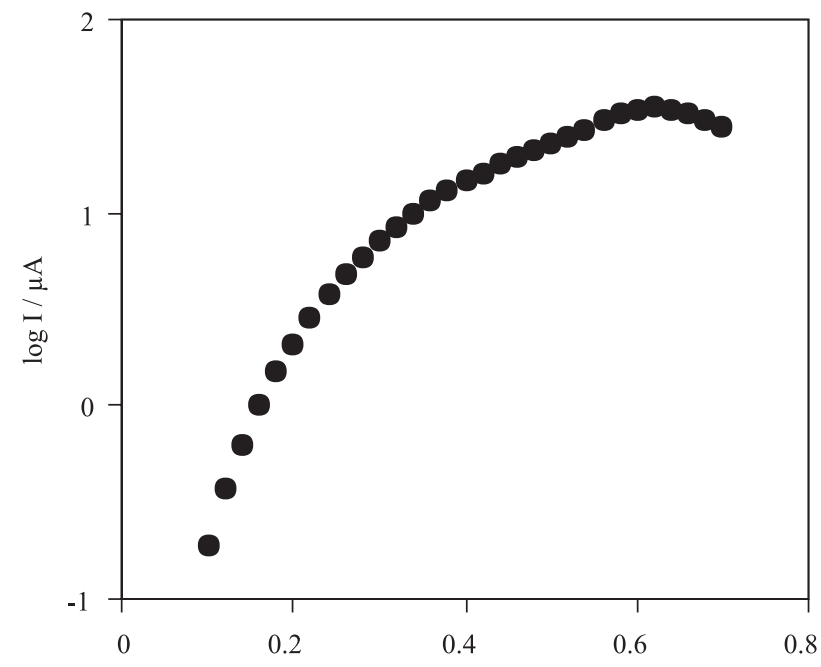

$\mathrm{E} / \mathrm{V}$ vs SCE

Figure 3. A typical Tafel plot derived from current-potential curves obtained on the GC/CoPCNF electrode at $4 \mathrm{mmol} \mathrm{L}^{-1}$ of thiosulfate.

$=0.7$. If assumed two electron it must be admitted $\alpha=0.84$ which is not a common value, because for most of electrode processes $\alpha$ ranges between 0.7 and 0.3. ${ }^{36}$

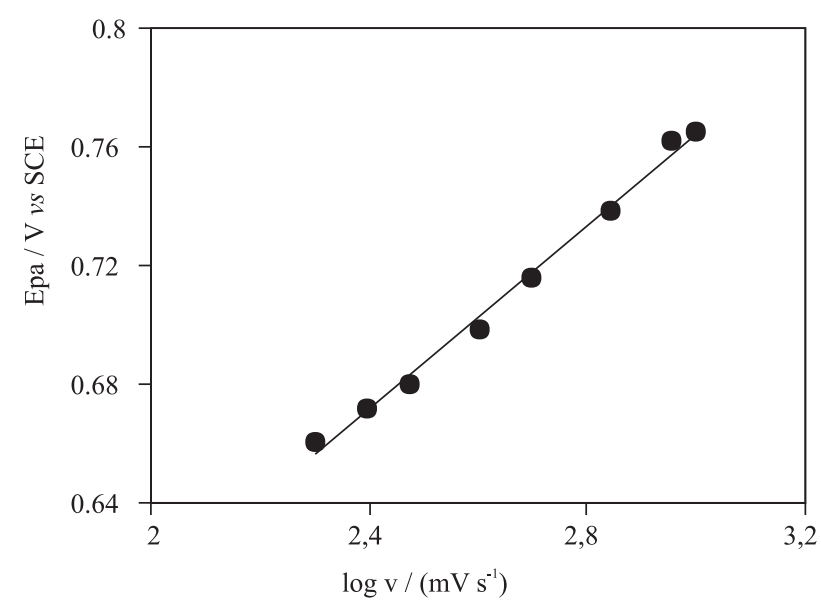

Figure 4. The anodic peak potential versus $\log \mathrm{v}$ derived from the voltammograms for $4 \mathrm{mmol} \mathrm{L}^{-1}$ thiosulfate. Supporting electrolyte as in Figure 1.

Determination of diffusion coefficient of thiosulfate in the solution.

Chronoamperometry. Chronoamperometry as well as other electrochemical methods may be used for the investigation of electrode processes at chemically modified electrode. ${ }^{37}$ Chronoamperometry was used for the estimation of the diffusion coefficient of thiosulfate in the solution. For an electroactive material with diffusion coefficient $\mathrm{D}$, the current corresponding to the electrochemical reaction (under diffusional control) is described by Cottrell's law ${ }^{38}$

$\mathrm{I}=\mathrm{nFAD}^{1 / 2} \mathrm{C} \pi^{-1 / 2} \mathrm{t}^{-1 / 2}$ 
where $\mathrm{D}$ and $\mathrm{C}$ are the diffusion coefficient $\left(\mathrm{cm}^{2} \mathrm{~s}^{-1}\right)$ and bulk concentration $\left(\mathrm{mol} \mathrm{cm}^{-3}\right)$, respectively. In the presence of thiosulfate the forward and backward potentials were $800 \mathrm{mV}$ and $0.0 \mathrm{mV}$ respectively. In the presence of thiosulfate at long experimental times $\left(\mathrm{t}>2 \mathrm{~s}_{\text {or }} \mathrm{t}^{-1 / 2}<0.5\right)$ the $\mathrm{KCo}\left[\mathrm{Fe}^{\mathrm{II}}(\mathrm{CN})_{5} \mathrm{NO}\right]$ oxidation is complete and the rate of electrocatalyzed thiosulfate oxidation exceeds that of thiosulfate diffusion from the bulk to the film-solution interface and therefore the current has a diffusional nature. A plot of I versus $\mathrm{t}^{-1 / 2}$ gives a straight line and the slope of such a line can be used to estimate the diffusion coefficient of thiosulfate (D). The mean value of $\mathrm{D}$ was found to be $6.46 \times 10^{-6} \mathrm{~cm}^{2} \mathrm{~s}^{-1}$ (Figure $5 \mathrm{~A}$ ).

By RDE Voltammetry. The steady-state I-E curves for the oxidation of thiosulfate at a CoPCNF film modified rotating GC disk electrode under various experimental conditions were recorded. In the case that solely the mass-
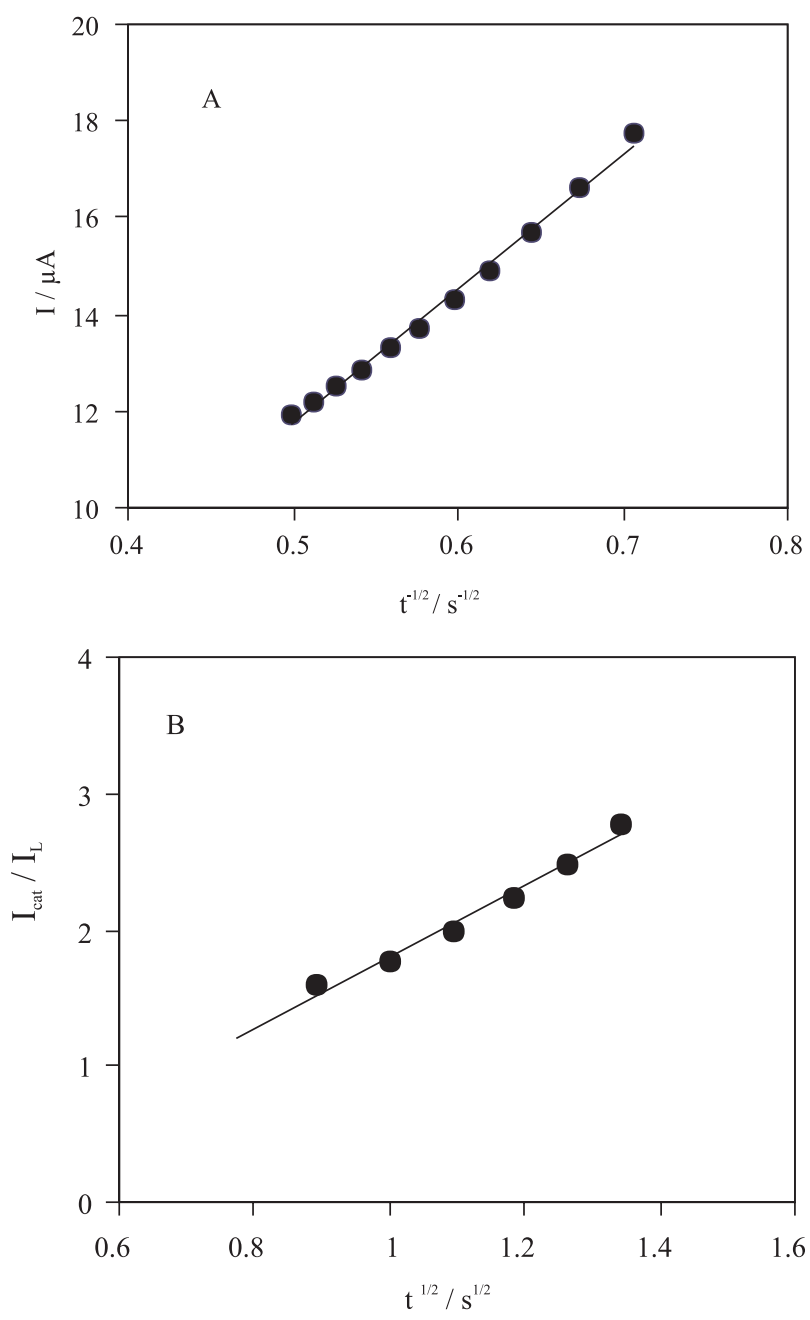

Figure 5. A) plot of I versus $\mathrm{t}^{-1 / 2}$ derived from the chronoamperogram in the presence of $4 \mathrm{mmol} \mathrm{L}^{-1}$ thiosulfate. B) plot of $\mathrm{I}_{\text {cat }} / \mathrm{I}_{\mathrm{L}} v s \mathrm{t}^{1 / 2}$ derived from the chronoamperogram data in the absence and presence of $4 \mathrm{mmol} \mathrm{L}^{-1}$ thiosulfate. Supporting electrolyte as in Figure 1. transfer process in the solution controls the oxidation of thiosulfate at the surface-modified GC electrode, the relationship between the limiting current and rotation speed should obey the Levich equation ${ }^{39}$

$\mathrm{I}_{1}=\mathrm{I}_{\mathrm{Lev}}=0.620 \mathrm{nAD}^{2 / 3} v^{-1 / 6} \omega^{1 / 2} \mathrm{C}_{\mathrm{o}}$

Where $\mathrm{D}, v, \omega$ and $\mathrm{C}_{\mathrm{o}}$ are the diffusion coefficient, the kinematic viscosity, the rotation speed and the bulk concentration of the reactant in the solution, respectively, and all other parameters have their conventional meanings. On the basis of equation 3 , a plot of limiting current $\mathrm{I}_{1}$ versus $\omega^{1 / 2}$ should be a straight line. Under extreme conditions, the plot of $\mathrm{I}_{1}$ versus $\omega^{1 / 2}$ become nonlinear, indeed cross exchange process between substrate and redox sites of the film-solution interface is also important factor in the rate-limiting process. The value of $\mathrm{D}$ from the slope of Levich equation was found to be $6.53 \times 10^{-6} \mathrm{~cm}^{2} \mathrm{~s}^{-1}$. Determination of catalytic rate constant of thiosulfate in
the solution

When thin films and high substrate (thiosulfate) concentrations are used, the contribution of thiosulfate and electron diffusion within the CoPCNF film in the limiting of the rate are negligibly small and the masstransport process in the solution and the electron crossexchange reaction become dominant and the heterogeneous rate constant of electron cross-exchange between the CoPCNF redox sites, $\mathrm{k}$, can be determined by three different electrochemical techniques.

Cyclic voltammetry. Andrieux and Saveant derived an equation between the catalytic current $\mathrm{I}_{\mathrm{c}}$, and kinetic parameters (substrate concentration, catalyst surface concentration $\Gamma$, catalytic rate constant $\mathrm{k}$ and scan rate $v) .{ }^{40}$ For large kinetic parameters (small $\mathrm{n}$, large $\mathrm{k}$ and $\mathrm{G}$ ) a peaked cyclic voltammogram with peak current:

$\mathrm{I}_{\mathrm{p}}=0.496 \mathrm{nFSc}_{0} \mathrm{D}^{1 / 2}(\mathrm{~F} v / \mathrm{RT})^{1 / 2}$

has been calculated. Where $v, \mathrm{~S}$ and $\mathrm{c}_{\mathrm{o}}$ are the scan rate, the electrode surface area, and the bulk concentration of substrate respectively and all other parameters have their conventional meanings. The low values of $\mathrm{k}$ results in a value of coefficient lower than 0.496 in equation 4 .

For scan rates $\left(20-60 \mathrm{mVs}^{-1}\right)$, thiosulfate concentration of $4 \mathrm{mmol} \mathrm{L}^{-1}$ and a surface coverage of $5 \times 10^{-8} \mathrm{~mol} \mathrm{~cm}^{-2}$ (the surface coverage evaluated from the equation of $\Gamma=\mathrm{Q} /$ $\mathrm{nF}$, where $\mathrm{Q}$ is the charge obtained by integrating the 
anodic peak under the background correction at a low scan rate such as $10 \mathrm{mVs}^{-1}$ ) we find the average value of this constant to be 0.441 . According to the approach of Andeieux and Saveant, using Figure 1(a) in reference ${ }^{40}$ we calculated a mean value of $5.59 \times 10^{2}\left(\mathrm{~mol} \mathrm{~L}^{-1}\right)^{-1} \mathrm{~s}^{-1}$ for $\mathrm{k}$.

Chronoamperometry. Chronoamperometry can be used for the evaluation of the kinetics (k). For an electroactive material with diffusion coefficient $\mathrm{D}$, the current corresponding to the electrochemical reaction (under diffusional control) is described by Cottrell's law. ${ }^{38}$ At intermediate times ( $\mathrm{t}=0.2-4 \mathrm{~s}$ in the present work) the catalytic current $\left(\mathrm{I}_{\text {cat }}\right)$ is dominated by the rate of the electron cross-exchange between CoPCNF redox sites and thiosulfate and the rate constant is determined according to the method described in the literature, ${ }^{41}$ using equation 5

$\mathrm{I}_{\text {cat }} / \mathrm{I}_{\mathrm{L}}=\gamma^{1 / 2}\left[\pi^{1 / 2} \operatorname{erf}\left(\gamma^{1 / 2}\right)+\exp (-\gamma) / \gamma^{1 / 2}\right]$

where $I_{\text {cat }}$ and $I_{L}$ are the currents of the CoPCNF/ GC electrode in the presence and absence of thiosulfate, respectively, and $\gamma=\mathrm{kC}_{0} \mathrm{t}\left(\mathrm{C}_{\mathrm{o}}\right.$ is the bulk concentration of thiosulfate ) and $\operatorname{erf}\left(\gamma^{1 / 2}\right)$ is the argument of the error function. In the cases that $\gamma$ exceeds 2 , the error function is almost equal to 1 and the above equation can be reduced to

$\mathrm{I}_{\text {cat }} / \mathrm{I}_{\mathrm{L}}=\gamma^{1 / 2} \pi^{1 / 2}=\pi^{1 / 2}\left(\mathrm{kC}_{\mathrm{o}} \mathrm{t}\right)^{1 / 2}$

where $\mathrm{k}, \mathrm{C}_{\mathrm{o}}$, and $\mathrm{t}$ are the catalytic rate constant $((\mathrm{mol}$ $\left.\left.\mathrm{L}^{-1}\right)^{-1} \mathrm{~s}^{-1}\right)$, the bulk concentration of thiosulfate $\left(\mathrm{mol} \mathrm{L}^{-1}\right)$ and time elapsed (s). From the slope of the $\mathrm{I}_{\text {cat }} / \mathrm{I}_{\mathrm{L}} v s \mathrm{t}^{1 / 2}$ plot, we can calculate the value of $\mathrm{k}$ for a given concentration of thiosulfate. Figure 5 B shows one such plot, constructed from the chronoamperograms for the $\mathrm{CoPCNF} / \mathrm{GC}$ electrode in the absence and presence of 4 mmol L $\mathrm{L}^{-1}$ thiosulfate, and value for $\mathrm{k}$ was found to be $5.56 \times 10^{2}\left(\mathrm{~mol} \mathrm{~L}^{-1}\right)^{-1} \mathrm{~s}^{-1}$ which is in good agreement with those obtained from the two other techniques.

The results obtained from the cyclic voltammetry, chronoamperometry and RDE voltammetry lead to the conclusion that the overall electrochemical oxidation of thiosulfate under these conditions might be controlled by the diffusion of thiosulfate in the solution and a crossexchange process between thiosulfate and the redox sites of the CoPCNF film. The oxidation of thiosulfate at conventional electrodes is well documented and is known to proceed via two consecutive one-electron transfer processes involving the participation of a radical anion intermediate to form thiosulfate. ${ }^{42}$ Under solution conditions, the process according to a heterogeneous $\mathrm{EC}^{\prime}$ catalytic mechanism can be expressed as follows:

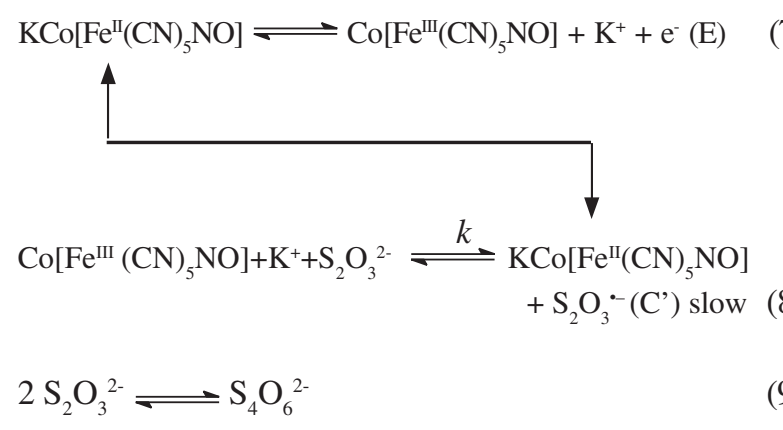

The overall chemical reaction is as follows:

$$
\begin{aligned}
& 2 \mathrm{Co}\left[\mathrm{Fe}^{\mathrm{III}}(\mathrm{CN})_{5} \mathrm{NO}\right]+2 \mathrm{~K}^{+}+2 \mathrm{~S}_{2} \mathrm{O}_{3}{ }^{2-} \rightleftharpoons 2 \mathrm{KCo}\left[\mathrm{Fe}^{\mathrm{II}}(\mathrm{CN})_{5} \mathrm{NO}\right] \\
& +\mathrm{S}_{4} \mathrm{O}_{6}{ }^{2-}
\end{aligned}
$$

The rate constant for reaction in equation 8 evaluated by cyclic voltammetry, chronoamperometry and RDE voltammetry.

RDE Voltammetry. A detailed description of the kinetics process at modified electrodes has been given by Andrieux et al. ${ }^{43}$

$\frac{1}{I_{l}}=\frac{1}{I_{\text {Lev }}}+\frac{1}{n F A C_{o} k \Gamma_{m}^{o}\left[1-\left(I_{l} l / F A C_{p}^{o} D e\right)\right]}$

Where $\mathrm{A}, \mathrm{k}, \Gamma_{\mathrm{m}}^{0}, 1, \mathrm{c}_{\mathrm{p}}^{0}$ and $\mathrm{D}_{\mathrm{e}}$ are the electrode area, the rate constant for the catalytic reaction, the surface concentration of the catalyst in a monolayer, the film thickness, the total volume concentration of catalyst in the film and the diffusion coefficient of electrons in the film.

When the mass-transfer process in the solution and the catalytic reaction become dominant, the term [1-( $\mathrm{I}_{1} 1 /$ $\left.\left.\mathrm{FAC}_{\mathrm{p}}^{0} \mathrm{D}_{\mathrm{e}}\right)\right]$ is essentially equal to unity and equation 11 reduces to the Koutecky-Levich equation and is used for kinetics analysis.

$\frac{1}{I_{l}}=\frac{1}{n F A C_{o} k \Gamma}+\frac{1}{0.62 n F A D^{2 / 3} v^{-1 / 6} C_{o} \omega^{1 / 2}}$

where $\mathrm{A}, \mathrm{C}_{\mathrm{o}}, \mathrm{k}$ and $\mathrm{G}$, are the electrode area $\left(\mathrm{cm}^{2}\right)$, substrate concentration $\left(\mathrm{mol} \mathrm{cm}{ }^{-3}\right)$, catalytic rate constant $((\mathrm{mol}$ $\left.\mathrm{L}^{-1}\right)^{-1} \mathrm{~s}^{-1}$ ), surface coverage $\left(\mathrm{mol} \mathrm{cm} \mathrm{cm}^{-2}\right.$ ). According to equation 6 the plot of $\mathrm{I}^{-1}$ versus $\omega^{-1 / 2}$ gives a straight line. The value of the rate constant (k) for the catalytic reaction can be obtained from the intercept of the Koutecky-Levich plot. The value of $\mathrm{k}$ was found to be $5.67 \times 10^{2}(\mathrm{~mol}$ $\left.\mathrm{L}^{-1}\right)^{-1} \mathrm{~s}^{-1}$ using $\Gamma=5 \times 10^{-8} \mathrm{~mol} \mathrm{~cm} \mathrm{~cm}^{-2}$. Figure 6 shows a typical RDE voltamogramm for $4 \mathrm{mmol} \mathrm{L}^{-1}$ solution of 
thiosulfate. The slope of the Koutecky-Levich equation is dependent on the reactant concentration $\mathrm{C}_{\mathrm{o}}$. The reverse relationship between the slope of Koutecky-Levich plot and thiosulfate concentration confirms that the catalytic reaction is first order with respect to the concentration of thiosulfate.

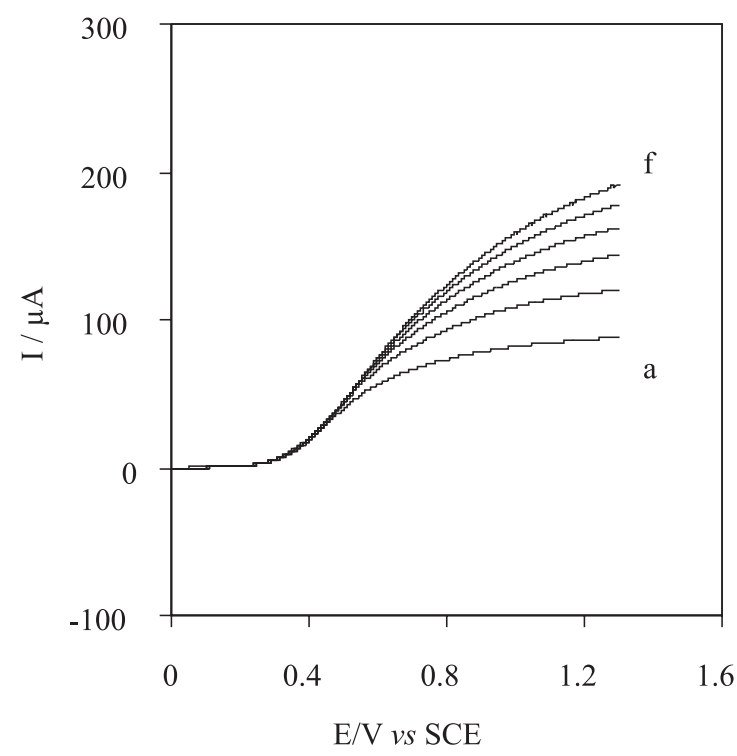

Figure 6. Rotating disk electrode voltammograms obtained for the oxidation of $4 \mathrm{mmol} \mathrm{L}^{-1}$ thiosulfate at GC / CoPCNF electrode. The rotation speeds are in rpm (a-f: 500, 1000, 1500, 2000, 2500, 3000 rpm, respectively). Scan rate: $20 \mathrm{mVs}^{-1}$.

\section{Conclusions}

The experimental results reported above demonstrate that the CoPCNF film modified GC electrode can catalyze the electrooxidation of thiosulfate via a surface layer mediated charge-transfer. The kinetic process of the catalytic reaction can be explained using cyclic voltammetry, chronoamperometry and RDE voltammetry. The results obtained for rate constant $\mathrm{k}$, diffusion coefficient of thiosulfate D in the solution by different approaches are in good agreement.

On the basis of results obtained it is apparent that the cobalt pentacyanonitrosylferrate modified GC electrode, exhibits a good stability and mediator activity for the electrochemical oxidation of thiosulfate. The CoPCNF film modified GC electrode can be prepared simply and rapidly and can be used as a sensor for thiosulfate determination.

\section{References}

1. Wu, P.; Cai, C.; J. Solid State Electrochem. 2004, 8, 538.

2. Liu, S.Q.; Chen, H.Y.; J. Electroanl. Chem. 2002, 528, 190.

3. Wang, J.; Zhang, X.; Prakash, M.; Anal. Chim. Acta 1999, 395,11 .

4. Lin, M. S.; Shih, W.C.; Anal. Chim. Acta 1999, 381, 183.
5. Malik, M.A.; Horanyi, G.; Kulesza, P.J.; Inzlet, G.; Kertesz, V.; Schmidt, R.; Czirok, E.; J. Electroanl. Chem. 1998, 452, 57.

6. Cataldi, T.R.I.; Benedetto, G.E.D.; Bianchini, A.; Electroanalysis 1998, 10, 1163.

7. Liu, S.L.; Li, H.; Jiang, M.; Li, P.; J. Electroanl. Chem. 1997, 426, 27.

8. Liu, C.; Dong, S.; Electroanalysis 1997, 9, 838.

9. Joseph, J.; Gomathi, H.; Rao, G.P.; J. Electroanl. Chem. 1991, $304,263$.

10. Humphrey, B.D.; Sinha, S.; Bocarsly, A.B.; J. Phys. Chem. 1987, 91, 586.

11. Razmi-Nerbin, H.; Hossaini Sadr, M.; Habibi-A, B.; J. Electroanl. Chem. 2005, 574, 207.

12. Pournaghi-Azar, M.H.; Dastangoo, H.; J. Electroanl. Chem. 2004, 567, 211.

13. Pournaghi-Azar, M.H.; Sabzi, R. E.; Electroanalysis 2004, $16,860$.

14. Pournaghi-Azar, M.H.; Haydarpour, M.; Dastangoo, H.; Anal. Chim. Acta 2003, 497, 133.

15. Pournaghi-Azar, M.H.; Dastangoo, H.; Electrochim. Acta 2003, 48, 1797.

16. Pournaghi-Azar, M.H.; Sabzi, R.E.; J. Electroanl. Chem. 2003, 543, 115

17. Pournaghi-Azar, M.H.; Dastangoo, H.; Electrochim. Acta 2003, 48, 1797.

18. Razmi-Nerbin, H.; Pournaghi-Azar, M.H.; J. Solid State Electrochem. 2002, 6, 126.

19. Pournaghi-Azar, M.H.; Razmi-Nerbin, H.; Electroanalysis 2001, 13, 465.

20. Pournaghi-Azar, M.H.; Razmi-Nerbin, H.; J. Electroanl. Chem. 2000, 488, 17.

21. Teixeira, M.F.S.; Marcolino-Junior, L.H.; Fatibello-Filho, O.; Dockal, E.R.; Cavalheiro, E.T.G.; J. Braz. Chem. Soc. 2004, $15,803$.

22. Shankaran, D.R.; Narayanan, S.S.; Sens. Actuators B 2002, 86, 180.

23. Golabi, S.M.; Zare, H.R.; J. Electroanl. Chem. 1999, 465, 168.

24. Abbaspour, A.; Kamyabi, M.A.; J. Electroanl. Chem. 2005, 576, 73.

25. Zhou, D.M.; Ju, H.X.; Chen, H.Y.; J. Electroanl. Chem. 1996, 408, 219.

26. Xun, Z.; Cai, C.; Xing, W.; Lu, T.; J. Electroanl. Chem. 2003, $545,19$.

27. Xu, F.; Gao, M.; Wang, L.; Zhou, T.; Jin, L.; Jin, J.; Talanta 2002, 58, 427.

28. Zhang, L.; Lin, X.; Analyst 2001, 126, 367.

29. Zhang, L.; Sun, Y.; Lin, X.; Analyst 2001, 126, 1760.

30. Yu, A.M.; Chen, H.Y.; Anal. Chim. Acta 1997, 344, 181.

31. Casella, I.G.; Guascito, M.R.; Electroanalysis 1997, 9, 1381.

32. Yu, A.M.; Zhang, H.L.; Chen, H.Y.; Electroanalysis 1997, 9, 788. 
33. Garjonyte, R.; Malinauskas, A.; Sens. Actuators B 1998, 46, 236.

34. Wang, P.; Jing, X.; Zhang, W.; J. Solid State Electrochem. 2001, 5, 369.

35. Harrison, J.A.; Khan, Z.A.; J. Electroanl. Chem. 1970, 28, 153.

36. Bard, A.J.; Faulkner, L.R.; Electrochemical Methods. Fundamentals and Applications, Wiley: New York, 1980, ch. 3.

37. Kuo, K.N.; Murray, R.W.; J. Electroanal. Chem. 1982, 131, 37.

38. Bard, A.J.; Faulkner, L.R.; Electrochemical Methods. Fundamentals and Applications, Wiley: New York, 1980, ch. 5.
39. Bard, A.J.; Faulkner, L.R.; Electrochemical Methods. Fundamentals and Applications, Wiley: New York, 1980, ch. 9.

40. Andrieux, C.P.; Saveant, J.M.; J. Electroanal. Chem. 1978, 93, 163.

41. Z. Galus; Fundamentals of Electrochemical Analysis, Ellis Horwood Press: New York, 1976, ch. 10.

42. Carvalho, M.de; Schwedt, G.; Anal. Chem. Acta 2001, 436, 293.

43. Andrieux, C.P.; Dumas-Bouchiat, J.M.; Saveant, J.M.; J. Electroanal. Chem. 1982, 131, 1.

Received: February 4, 2005 Published on the web: October 6, 2005 